\title{
The Link between Human Resources in Science and Technology and Regional Economic Development in the EU
}

\author{
Jan Hunady \\ Faculty of Economics, Matej Bel University in Banska Bystrica, Slovakia \\ Marta Orviska \\ Faculty of Economics, Matej Bel University in Banska Bystrica, Slovakia \\ Peter Pisar \\ Faculty of Economics, Matej Bel University in Banska Bystrica, Slovakia
}

\begin{abstract}
Science and technology is seen as the key factor supporting the performance of regional innovation systems. Furthermore, the innovation intensity in the region could be often crucial for regional economic development. Our research aims to examine the potential link between the economic development of the region and the intensity of science and technology activities proxied by the share of employees in science and technology. The analysis is based on panel data for NUTS2 regions of EU member states in the period 2003-2014. We conducted correlation analysis, panel Granger causality tests and regression analysis. Our results suggest the existence of a significant positive correlation between GDP per capita and the share of employees in science and technology. Moreover, the regions with higher intensity of science and technology activities are mostly characterized by relatively low unemployment rates and a higher proportion of residents with a university education.
\end{abstract}

Keywords: science and technology, regional development, university education, innovation, economic development

JEL classification: O30, 123, R59

Acknowledgments: This research was supported by the Slovak Research and Development Agency (APVV), APVV-14-0512 "Universities and regional development".

\section{Introduction}

Despite the existence of several supranational tolls to eliminate regional disparities, there are still significant differences in regional economic development within the EU. The economic growth of the regions is often attributed to technological change and innovation intensity. The ability of poor regions to catch up with the rich ones is closely related to their ability to generate sufficient investments, but also of its innovation capacity (Fagerberg, 2010). The institutional characteristics, knowledge infrastructures and knowledge transfer systems at regional level appear to be crucial for promoting innovations at regional level (Doloreux and Parto, 2005).

Inovation consists of knowledge that arises as a result of scientific, research and development activities and, consequently, the ability of workers to apply them into practice (Hudec et al., 2009). In line with this statement, especially the intensity of science, research and development together with the proportion of tertiary 
educated people are those factor supporting the innovation performance and thus also the regional economic development (Badinger, Tondl, 2003; Sterlacchini, 2008). The accumulation of intellectual capital is one of the main factors that create differences in the productivity of individual regions (Fischer, Scherngell, Reismann, 2009). Hence, the support of science and technology activities within the region seems to be beneficial for maintaining economic development of the region. Furthermore, there is also some other direct positive effect of higher education institutions located in the region. However, the extent of these benefits depends on their quality and policy settings in the region (Arbo, Benneworth, 2007).

In general we can assume that higher intensity of science and technology in the region could have some positive consequences on regional development. Furthermore, knowledge infrastructure of the region is crucial stimuli for promoting innovation activities in the region (Doloreux and Parto, 2005). However, more science and technology could not inevitably mean more knowledge. There are also significant differences in innovation capacity. Thus, more knowledge does not always lead to the increase in innovation performance. The actual acquisition of knowledge can be made either from local sources within the region or from external environment or other regions. As stated by Pastor, Šipikal, Rehak (2013), the process of knowledge acquisition from other regions is very important source of regional development. Perhaps, this way of acquiring knowledge is even more important for less developed regions.

According to Sandu (2012) human resources in science and technology are one of the main indicators describing the current research and innovation potential of the region together with number of patents, publications and R\&D expenditures. Moreover, the amount of innovation activities in the region could be indirectly measured by the proportion of research and development employees (Fritsch, Schroeter, 2011).

With respect to this, our paper aims to examine the potential link between the intensity of science and technology in the regions and their economic development. The intensity of science and technology is proxied by the share of human resources employed in these areas. We further describe the methodology and data used in the analysis in the next section of our paper. Key results are summarized and discussed in the third section. Finally we make some conclusions and remarks in the final section of the paper.

\section{Methodology and Data}

Our main scientific aim is to identify potential link between the share of employees in science and technology and the economic development of the region measured by GDP per capita. With respect to this aim we decided to analyse empirical data. In this section we describe our methodology as well as the data in a more detail. Our dataset consist of panel data for NUTS 2 regions in EU countries retrieved from EUROSTAT (2016) database. The data include several variables for 317 NUTS 2 regions in the period 2004-2014. Thus, we get together more than 3217 non-missing observations. We used especially four variables in the analysis. These are summarized in the Table 1. Two most important variables are regional GDP per capita and regional number of employees in science and technology. 
Table 1

Description of variables used in the analysis

\begin{tabular}{|c|c|c|}
\hline variable & Description & source \\
\hline GDP per capita & $\begin{array}{l}\text { Regional gross domestic product (GDP) by } \\
\text { NUTS } 2 \text { regions. Purchasing power standard } \\
\text { (PPS) per inhabitant. }\end{array}$ & $\begin{array}{l}\text { Eurostat } \\
\text { database } \\
\text { [nama_r_e2gdp] }\end{array}$ \\
\hline $\begin{array}{lr}\text { Share } & \text { of } \\
\text { employees } & \text { in } \\
\text { science } & \text { and } \\
\text { technology } & \end{array}$ & $\begin{array}{l}\text { Share of employees in science and } \\
\text { technology on total number employment } \\
\text { by NUTS } 2 \text { regions. Full-time equivalent (FTE). }\end{array}$ & $\begin{array}{l}\text { Eurostat } \\
\text { database } \\
\text { [rd_p_persreg) ] }\end{array}$ \\
\hline $\begin{array}{l}\text { Tertiary } \\
\text { education }\end{array}$ & $\begin{array}{l}\text { The share of population with tertiary } \\
\text { education } n \text { NUTS } 2 \text { regions. }\end{array}$ & $\begin{array}{l}\text { Eurostat } \\
\text { database } \\
\text { [rd_p_persreg }\end{array}$ \\
\hline Unemployment & Rate of unemployment in NUTS2 regions. & $\begin{array}{l}\text { Eurostat } \\
\text { database } \\
\text { [rd_p_persreg }\end{array}$ \\
\hline
\end{tabular}

Source: Authors

We examined the potential relationship between regional share of employees in science and technology and regional GDP per capita using the panel Granger causality tests and the panel fixed-effects and random effects models. The choice between random effects and fixed-effects application was done based on the results of the Hausman test. Variables used in the models were tested for weak stationarity using the panel stationarity test. According to the results of these tests we can conclude that all selected variables are found to be non-stationary at their levels but appear to be stationary at the first differences. Hence, we decided to use the first differences of the variables in all regression models.

\section{Results and Discussion}

In first stage we examined the potential correlation between selected variables. The Pearson correlation coefficients between each pair of variables are summarized in the Table 2.

Table 2

Correlation matrix of selected variables

\begin{tabular}{|c|c|c|c|c|}
\hline & $\begin{array}{c}\text { GDP } \\
\text { per } \\
\text { capita }\end{array}$ & $\begin{array}{l}\text { Number of } \\
\text { employees in } \\
\text { science and } \\
\text { technology } \\
\text { (share) }\end{array}$ & $\begin{array}{l}\text { Tertiary } \\
\text { educati } \\
\text { on }\end{array}$ & $\begin{array}{c}\text { Unemploymen } \\
t\end{array}$ \\
\hline GDP per capita & 1.000 & 0.716 & 0.435 & -0.429 \\
\hline $\begin{array}{l}\text { Share of employees in } \\
\text { science and } \\
\text { technology }\end{array}$ & 0.716 & 1.000 & 0.497 & -0.431 \\
\hline $\begin{array}{l}\text { Tertiary education } \\
\text { (share) }\end{array}$ & 0.435 & 0.497 & 1.000 & -0.036 \\
\hline Unemployment & -0.429 & -0.431 & -0.036 & 1.000 \\
\hline
\end{tabular}

Source: Authors based on the data from Eurostat database 
As we can see, there is a strong positive correlation between regional GDP per capita and the share of employees in science and technology. There are also moderate positive correlations between the share of people with tertiary education in the region, regional GDP per capita and the share of employees in science and technology. On the other hand, all three variables are negatively correlated with regional unemployment. Thus, the regions with more intensive science and technological activities have in general less unemployment. The negative correlation between GDP per capita and unemployment is of course in line with theoretical assumption.

In the next part of the analysis, we focus our attention on a potential relation between GDP per capita and the share of employees in science and education. In order to test the direction of the causality we applied Granger causality tests. The results that can be seen in Table 3, strongly suggest that there is causality in Granger sense arising from the employment in science and technology to regional GDP per capita. On the other hand, the potential effect in opposite direction is not statistically significant.

Table 3

The results of Granger causality test

\begin{tabular}{ccc}
\hline & F-statistic & F-statistic \\
\hline $\begin{array}{c}\text { Number of lags: } \\
\Delta \text { GDP per capita does not Granger Cause } \\
\Delta \text { Share of employees in science and } \\
\text { technology }\end{array}$ & 0.4706 & 2 lags \\
$\begin{array}{c}\Delta \text { Share of employees in science and } \\
\text { technology does not Granger Cause } \Delta \text { GDP } \\
\text { per capita }\end{array}$ & $10.393^{* * *}$ & $27.651^{* * *}$ \\
Number of observations & 3154 & 2837 \\
\hline
\end{tabular}

Source: Authors based on the data from Eurostat database

Finally, we analysed the potential relationship using the panel data regressions. We applied several different fixed effect panel regressions. All models were tested for autocorrelation and multicolinearity. Moreover, we also used standard errors robust for heteroscedasticity. The results of regressions (see Table 4) suggest that there is a significant positive effect of the share of employees in science and technology on regional GDP per capita. This effect is statistically significant at $10 \%$ or $5 \%$ level respectively. The share of people with tertiary education in the region appears to be insignificant with respect to GDP per capita. We also used the share of employees in science and technology lagged by one period as independent variable. The potential positive effect is even more significant in this case as we can see in regression 1.4 . 
Table 4

Results of panel regression model

\begin{tabular}{|c|c|c|c|c|c|}
\hline \multicolumn{6}{|c|}{ Dependent variable: $\triangle$ GDP per capita } \\
\hline & 1.1 & 1.2 & 1.3 & 1.4 & 1.5 \\
\hline$C$ (fixed effects) & $\begin{array}{c}-0.116^{* *} \\
(-2.16)\end{array}$ & $\begin{array}{l}-0.124^{*} \\
(-2.28)\end{array}$ & $\begin{array}{c}-0.112^{* *} \\
(-2.09)\end{array}$ & $\begin{array}{c}-0.204^{* * *} \\
(-3.40)\end{array}$ & $\begin{array}{c}-0.097^{*} \\
(-1.92)\end{array}$ \\
\hline $\begin{array}{l}\Delta \text { Share of } \\
\text { employees in } \\
\text { science and } \\
\text { technology }\end{array}$ & $\begin{array}{l}0.006^{*} \\
(1.94)\end{array}$ & $\begin{array}{c}0.081^{* *} \\
(2.13)\end{array}$ & $\begin{array}{c}0.078^{* *} \\
(2.19)\end{array}$ & & $\begin{array}{c}0.138^{* * *} \\
(3.58)\end{array}$ \\
\hline $\begin{array}{l}\Delta \text { Share of } \\
\text { employees in } \\
\text { science and } \\
\text { technology2 }\end{array}$ & & & & & $\begin{array}{c}-0.031^{* * *} \\
(-3.682)\end{array}$ \\
\hline $\begin{array}{c}\Delta \text { Share of science } \\
\text { and } \\
\text { technology }(\operatorname{lag}=1)\end{array}$ & & & & $\begin{array}{c}0.126^{* * *} \\
(3.61)\end{array}$ & \\
\hline$\Delta$ Tertiary education & $\begin{array}{l}-0.033 \\
(-0.92)\end{array}$ & $\begin{array}{l}-0.038 \\
(-1.03)\end{array}$ & $\begin{array}{c}0.005 \\
(-1.36)\end{array}$ & $\begin{array}{l}-0.010 \\
(-0.31)\end{array}$ & \\
\hline Fixed effects: & $\begin{array}{l}\text { Cross- } \\
\text { section FE }\end{array}$ & Period FE & $\begin{array}{l}\text { Cross- } \\
\text { section \& } \\
\text { period FE }\end{array}$ & $\begin{array}{l}\text { Cross- } \\
\text { section FE }\end{array}$ & $\begin{array}{l}\text { Cross- } \\
\text { section FE }\end{array}$ \\
\hline R2 & 0.20 & 0.005 & 0.20 & 0.21 & 0.20 \\
\hline Adjusted R2 & 0.12 & 0.002 & 0.12 & 0.12 & 0.12 \\
\hline Akaike criterion & 4.93 & 8.475 & 4.94 & 4.97 & 4.93 \\
\hline F-statistic & $2.411^{* * *}$ & $1.584^{*}$ & $2.395^{* * *}$ & $2.383^{* * *}$ & $2.47^{* * *}$ \\
\hline $\begin{array}{l}\text { Number of } \\
\text { observations }\end{array}$ & $\begin{array}{c}3471 \\
(11 \times 317)\end{array}$ & $\begin{array}{c}3271 \\
(11 \times 317)\end{array}$ & $\begin{array}{c}3271 \\
(11 \times 317)\end{array}$ & $\begin{array}{c}3271 \\
(11 \times 317)\end{array}$ & $\begin{array}{c}3271 \\
(11 \times 317)\end{array}$ \\
\hline
\end{tabular}

Note: symbols (.) denotes z-statistics and */* denotes statistically significant at the $1 / 5$ percent level. Standard errors have been corrected for heteroscedasticity

Source: Authors based on the data from Eurostat database

Furthermore, based on the results of regression 1.5 we can say the potential relationship between these two variables seems to be in nonlinear inverse U-shape form. This means that the GDP per capita rises with the increase in the share of employees in science and technology only to a certain point. The maximum appears to be approximately at $2.23 \%$. However, we can see that the $R$ squared is rather low in all models, which means that the intensity of science and technology in the region is still not the main factor affecting the regional GDP per capita.

\section{Conclusion}

Innovation supposes to be the key determinant of economic growth in the long-run. With respect to innovation performance, especially the science and technology seems to be the most important sector. Hence, we can say that universities and other research institutions are often inevitable when creating innovation in the region. The intensity of science and technology has been proxied by the share of 
human resources employed in this sector. We can assume that higher share of employees in science and technology could positively affect the regional economic development. We also take to the account control variable representing the share of people with tertiary education living in the region. This has been used because educational level supposes to be often very important factor with respect to knowledge creation and innovation. Of course the role of universities is again crucial in this case.

We found positive correlation between intensity of science and technology and economic development of the region. Based on our results, we can say that more human resources in science and technology could have some positive effect on the regional GDP per capita. This effect seems to be even stronger when taking to the account one year lag. However, we also found a certain turning point for this positive effect. Hence, it means that increasing the share of employment in science and technology beyond this point could not lead to any further positive effects on regional economic development. It is also important to mention that our approach does not capture all variables that could have an effect on regional economic development. Moreover, despite the fact that we have tested the models for reverse causality, the endogeneity could still be a problem in our case. Thus, it should be perhaps more appropriate to speak about certain correlations rather than strict causal effects.

\section{References}

1. Arbo, P., Benneworth, P. (2007), "Understanding the regional contribution of higher education institutions: A literature review", OECD Education Working Papers, Vol. 9 No 1.

2. Badinger, H., Tondl, G. (2003), "Trade, human capital and innovation: the engines of European regional growth in the 1990s." in Fingleton, B. (Ed.) European regional growth. Advances in Spatial Science, Berlin, Springer, pp. 215-239.

3. Doloreux, D., Parto, S. (2005), "Regional innovation systems: Current discourse and unresolved issues", Technology in society, Vol. 27 No. 2, pp. 133-153. doi:10.1016/j.techsoc.2005.01.002.

4. Fagerberg, J. (2010), "The changing global economic landscape: the factors that matter." in Solow, R. M., Touffut J. (Ed.), The Shape of the Division of Labour: Nations, Industries and Households. Edward Elgar, pp. 6-31. http://dx.doi.org/10.4337/9781849809122.

5. Fischer, M.M., Scherngell, T., Reismann, M. (2009), "Knowledge spillovers and total factor productivity: evidence using a spatial panel data model", Geographical Analysis, Vol. 41 No. 2, pp. 204-220.

6. Fritsch, M., Schroeter, A. (2011), "Why does the effect of new business formation differ across regions?", Small Business Economics, Vol. 36 No. 4, pp. 383-400.

7. Hudec, O. a kol. (2009). "Podoby regionálneho a miestneho rozvoja." Košice: Ekonomická fakulta TU.

8. Pástor, R., Šipikal, M., Rehák, Š. (2013), "Knowledge creation and knowledge acquisition in the software industry in Slovakia: the case study of Košice region", Regional Science Policy \& Practice, Vol. 5 No. 4, pp. 401-415.

9. Sandu, S. (2012), "Smart specialization concept and the status of its implementation in Romania", Procedia Economics and Finance, Vol. 3, pp. 236-242.

10. Sterlacchini, A. (2008), "R\&D, higher education and regional growth: Uneven linkages among European regions", Research Policy, Vol. 37 No. 6, pp. 1096-1107. 


\section{About the authors}

Jan Hunady, is assistant professor at the Faculty of Economics, Matej Bel University in Banska Bystrica, Slovakia. He received his PhD in public economics and services at Matej Bel Univeristy. He has already published a number of papers at conferences and journals, primarily in the area of public finance and innovation. He also participates on several research projects in the area of research policy and innovation. He has expertise in econometrics and econometrics package programs particularly panel data and time series analysis. Author can be contacted at jan.hunady@umb.sk.

Marta Orviska, is professor of finance, banking and investment at Matej Bel University. She is one of the most cited economists in Slovakia. Her research interests are focused on macroeconomics and public finance, including tax policy and tax evasion, standardisation, voting behaviour and the analysis of attitudes to, for example, NATO and the EU in the new applicant countries and new members of the EU, and to new technologies. In the period between 2000-2015 she held several positions in national and international projects in these areas and she has published a number of articles including in the European Journal of Political Economy, Journal of Common Market Studies, Social Indicators Research, Economics of Governance, Journal of Policy Modelling, Information Economics and Policy, Central European Journal of Public Policy, South East European Journal of Economics and Business, Politicka ekonomie, Drug Discovery Today and Nano Today. Author can be contacted at marta.orviska@umb.sk.

Peter Pisar, is associate professor of finance, banking and investment at Matej Bel University. He has been the Head of Department of Finance and Accounting since 2015 executive editor of the scientific journal Region Direct and project manager of Europe Direct Information Center Relay, European Commission, Brussels, REIC Banska Bystrica, Slovakia. His research is focused on European public finances, especially innovative financing and the evaluation of regional policy and public expenditure programs. In practice, he is also a consultant for the development and implementation of projects supported by EU funds and is particularly concerned with public policies supporting innovation. Author can be contacted at peter.pisar@umb.sk. 